
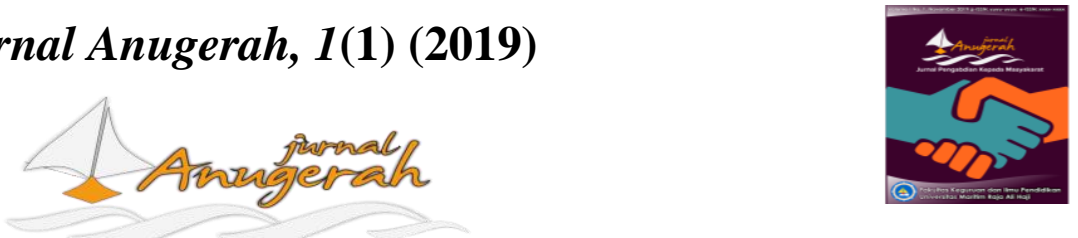

https://ojs.umrah.ac.id/index.php/anugerah

\title{
Desain Pembelajaran Berbasis Literasi Sains dan Berwawasan Kemaritiman Sebagai Hasil Pelatihan di SMAN 4 Tanjungpinang
}

\author{
Trisna Amelia ${ }^{* 1}$, Inelda Yulita ${ }^{2}$ \\ ${ }^{1,2}$ Universitas Maritim Raja Ali Haji, Tanjungpinang, Kepulauan Riau 29124, Indonesia \\ *e-mail korespondensi: trisna.amelia@umrah.ac.id \\ Pengiriman: 29 Oktober 2019; Diterima: 21 November 2019; Publikasi: 28 November 2019
}

\begin{abstract}
Abstrak
Mendesain pembelajaran menjadi bagian penting dari proses pencapaian tujuan pembelajaran. Demikian juga ketika guru hendak membekali siswa dengan literasi sains, juga harus diupayakan mulai dari desain pembelajarannya. Desain pembelajaran berbasis literasi sains menjadi sangat penting kedudukannya ketika orientasi pembelajaran sains tidak hanya sekadar untuk mencapai aspek kognitif, namun terlebih lagi kepada kecakapan peserta didik dalam mengaplikasikan sains serta memiliki sikap dan kemampuan mengambil keputusan berkaitan dengan sains dalam kehidupannya. Salah satu aspek yang penting dalam desain pembelajaran berbasis literasi sains yaitu relevansi konteks sains dengan konsep atau pengetahuan. Bagi siswa di daerah Kepulauan Riau, konteks kemaritiman menjadi sangat relevan untuk dibahas dalam batang tubuh sains sebagai ilmu pengetahuan. Melalui pelatihan yang sudah dilakukan secara intensif di SMA Negeri 4 Tanjungpinang, guru-guru biologi dan kimia dilatih untuk mendesain pembelajaran berbasis literasi sains dan bermuatan konteks kemaritiman. Desain pembelajaran yang dikembangkan mengacu kepada pendekatan STL (science and technology literacy) yang memiliki 5 tahapan pembelajaran yaitu tahap kontak, tahap elaborasi (konten), tahap kuroisiti, pengambilan keputusan, dan tahap nexus. Dari hasil pendampingan oleh fasilitator pelatihan, maka dihasilkan 2 desain pembelajaran (mata pelajaran biologi dan kimia). Konteks kemaritiman diintegrasikan dalam materi Keanekaragaman Hayati (untuk mata pelajaran Biologi) dan materi Minyak Bumi (untuk mata pelajaran Kimia).
\end{abstract}

Kata kunci: desain pembelajaran; biologi; kimia; literasi saintifik; matirim

\begin{abstract}
Learning designing becomes an important part of the process to achieve learning objectives. Likewise, when teachers enhancestudents' scientific literacy, the efforts must also be made from the learning design. The design of learning based on scientific literacy becomes very important when the orientation of science learning is not just to achieve cognitive aspects, but even more to the students' ability to apply science and have the attitude and ability to make decisions related to science in their lives. One important aspect in the design of learning based on scientific literacy is the relevance of the context of science to concepts or knowledge. For students inKepulauan Riau, the maritime context is very relevant to be discussed in the body of science. Through intensive training at SMA Negeri 4 Tanjungpinang, biology and chemistry teachers were trained to design science literacy-based learning and maritime-based contexts. The learning design developed refers to the STL (science and technology literacy) approach which has 5 stages of learning, namely the contact stage, the elaboration stage (content), the curriculum stage, decision making, and the nexus stage. From the results of the mentoring by the training facilitator, 2 learning designs were produced (biology and chemistry subjects). The maritime context is integrated in the material Biodiversity (for Biology) and Petroleum (for Chemistry).
\end{abstract}

Keywords:learning design; biology; chemistry; scientific literacy; maritime 


\section{Pendahuluan}

Desain pembelajaran merupakan pengembangan pengajaran secara sistematik yang digunakan secara khusus teori-teori pembelajaran unuk menjamin kualitas pembelajaran. Pernyataan tersebut mengandung arti bahwa penyusunan perencanaan pembelajaran harus sesuai dengan konsep pendidikan dan pembelajaran yang dianut dalam kurikulum yang digunakan.

Literasi Sains didefinisikan sebagai kapasitas untuk menggunakan pengetahuan ilmiah, mengidentifikasi pertanyaan dan menarik kesimpulan berdasarkan fakta untuk memahami alam semesta dan membuat keputusan dari perubahan yang terjadi karena aktivitas manusia (OECD, 2010). Secara praktis, literasi sains dapat dipahami sebagai kemampuan peserta didik dalam memahami sains, mengkomunikasikannya dan mengambil keputusan terhadap situasi yang terjadi di kehidupan sekitarnya. Mencermati definisi tersebut, tentu dapat dipahami bahwa literasi sains penting untuk membekali peserta didik untuk siap menghadapi situasi kehidupan nyata. Tanpa kemampuan literasi, peserta didik seolah-olah mempelajari berbagai hal namun mereka tidak mampu mengaplikasikan di dalam kehidupannya.

Mata pelajaran IPA (Sains) memiliki peran penting dalam meningkatkan kecakapan hidup termasuk tingkat kemelekan sains (literasi sains) peserta didik. Wenning (2011) mengutip pendapat O'Hearn menyatakan bahwa literasi sains meliputi 4 poin yakni: a) pengetahuan ilmiah dasar, b) sifat alami sains, c) proses sains, dan d) implikasi sosial dan budaya sains. Sedangkan menurut The National Science Education Standard indikator literasi sains terdiri atas 6 komponen yakni tingkat penguasaan: 1) sains sebagai inkuiri, 2) materi sains, 3) sains dan teknologi, 4) sains dalam perspektif personal dan sosial, 5) sejarah dan sifat alamiah sains, dan 6) kesatuan konsep dan proses sains.

Literasi sains akan berdampak pada perkembangan keterampilan berpikir siswa sebagai bagian dari komponen-komponen kecakapan hidup (Lestasi 2017). Berbagai hasil penelitian menjelaskan bahwa pendidikan dewasa ini harus membekali peserta didik dengan keterampilan untuk menghadapi tantangan global dan kebutuhan lingkungan kerja (Snow dan Dibner, 2016). Oleh karena itu peserta didik tidak hanya membutuhkan pengetahuan dan keterampilan motorik saja tetapi perlu dilengkapi dengan kecakapan hidup (life skills) yang merupakan sarana bagi tumbuhnya keterampilan berkomunikasi dan keterampilan menyelesaikan masalah-masalah aktual dalam kehidupan bermasyarakat sehari-hari. Untuk dapat melakukan hal tersebut, di sanalah diperlukan sumber daya manusia yang literate atau melek sains.

Kenyataannya, hasil tes PISA menunjukkan bahwa pelajar sekolah menengah di Indonesia memiliki tingkat literasi yang tergolong rendah. Berbagai penelitian yang dilakukan secara umum di Indonesia, menunjukkan bahwa kemampuan literasi sains peserta didik di Indonesia masih kurang sekali terutama pada kemampuan berpikir dan bekerja ilmiah (Diana dkk., 2015) Terkait hal ini, pendidik atau guru bidang sains memiliki tanggung jawab besar untuk berupaya mengembangkan literasi sains dalam proses pembelajaran. Pada dasarnya, berbagai upaya dapat dilakukan oleh pendidik dalam rangka meningkatkan literasi sains peserta didik, di antaranya adalah melalui penerapan berbagai strategi dan pendekatan pembelajaran serta pemanfaatan berbagai sumber belajar dan mengintegrasikannya dalam rancangan kegiatan pembelajaran.

Salah satu solusi yang dapat meningkatkan literasi sains peserta didik adalah melalui rancangan pembelajaran yang mengakrabkan sains kepada kehidupan riil peserta didik. Dengan kata lain, literasi sains dapat ditumbuhkan melalui isu-isu dan kondisi faktual yang dihadapi oleh peserta didik. Bagi peserta didik di Kepulauan Riau, lingkungan kemaritiman/ kelautan merupakan lingkungan paling dekat dan representatif yang kerap mereka hadapi dalam kehidupan sehari-hari. Terkait dengan pembelajaran sains yang menekankan pada terbentuknya literasi sains, mengemukakan kajian atau contoh-contoh riil mengenai berbagai aspek dan fenomena kemaritiman menjadi sangat relevan untuk dilakukan. Dengan memahami sains dari perspektif yang sangat dekat dengan kehidupan mereka tentu akan menjadikan pembelajaran sains itu lebih bermakna dan bermanfaat bagi mereka. Peserta didik mampu memahami, menganalisis, 
mengkomunikasikan, dan kemudian memutuskan tindakan yang layak terhadap lingkungan kemaritiman yang ada di sekitar mereka.

Persoalan di lapangan (SMA Negeri 4 Tanjungpinang) dalam pembelajaran sains, terutama biologi dan kimia, yang memberikan penekanan pada wawasan kemaritiman dengan tujuan menumbuhkembangkan literasi sains belum dilakukan. Pembelajaran masih menekankan hanya pada produk sains (pengetahuan tekstual), belum ada proses menghubungkan dengan fenomena ilmiah yang ada disekitar, apalagi mengarah kepada terbentuknya kecakapan hidup berkaitan dengan lingkungan kontekstual. Kapasitas dan pengalaman guru dalam mendesain pembelajaran berbasis wawasan kemaritiman dengan tujuan menumbuhkan literasi sains menjadi faktor pembatas dalam hal ini.

Merespon masalah ini, penulis menilai sangat penting dilakukan sebuah program kegiatan yang dapat memfasilitasi guru-guru biologi dan kimia untuk dapat mendesain pembelajaran berorientasi pada pembentukan literasi sains dengan mengintegrasikan wawasan kemaritiman. Penulis dalam hal ini juga sebagai pengusul memiliki kapasitas yang memadai dan relevan dengan kebutuhan stakeholder (guru biologi dan kimia). Aktivitas riset yang sudah dilakukan oleh pengusul menunjukkan kapasitas yang dimaksud, sebagaimana diuraikan sebagai berikut. Beberapa penelitian dimaksud seperti penelitian berjudul "Pengembangan Modul Bahasa Inggris untuk Biologi Berorientasi Literasi Sains untuk Mahasiswa Pendidikan Biologi" pada tahun 2016 yang dipublikasikan pada Jurnal Pedagogi Hayati (ojs.umrah.ac.id/index.php/pedagogihayati) dan peneltian berjudul "Desain Bahan Ajar Berbasis Literasi Sains: Hakekat Ilmu Kimia pada Konteks Air Laut" pada tahun 2017 yang dipublikasikan pada Seminar Nasional Kimia UNY (seminar.uny.ac.id/semnaskimia/content/semnas2017) dan Jurnal Pendidikan Sains (https://jurnal.unimus.ac.id/index.php/JPKIMIA/index).

Meninjau analisis situasional yang sudah dipaparkan, maka penulis mengusulkan program kegiatan yang dinilai dapat memberikan solusi bagi masalah-masalah yang ada di lapangan. Tema kegiatan yang dimaksud yaitu "Pelatihan Mendesain Pembelajaran Biologi dan Kimia Berbasis Kemaritiman untuk Membangun Literasi Sains Siswa SMA NEGERI 4 Tanjungpinang”. Tujuan kegiatan ini dilaksanakan adalah untuk meningkatkan kompetensi guru Biologi dan Kimia di SMA Negeri 4 Tanjungpinang dalam mendesain pembelajaran berbasis literasi sains dan bermuatan kemaritiman.

\section{Metode}

Solusi yang diajukan terkait permasalahan yang sudah dipaparkan adalah; perlu dilakukan beberapa hal sebagai solusi, yaitu:

1. Sosialisasi kepada guru-guru biologi dan kimia di SMA NEGERI 4 Tanjungpinangmengenai literasi sains dan pentingnya kedudukan literasi sains sebagai output pembelajaran sains

2. Pelatihan bagi guru-guru biologi dan kimia untuk menentukan konten-konten dalam pelajaran biologi dan kimia yang dekat kaitannya dengan wawasan kemaritiman.

Pelatihan bagi guru-guru biologi dan kimia untuk mendesain pembelajaran bermuatan wawasan kemaritiman dengan tujuan membangun literasi sains peserta didik.Secara umum, pelaksanaan program ini mengadopsi model siklus Deming (PDCA), yang terdiri dari 4 tahapan yaitu Plan, Do, Check, Act (Rencanakan, Kerjakan, Cek, Tindak lanjuti).

1. Plan

a. Sosialisasi kepada guru-guru biologi dan kimia mengenai pentingnya literasi sains, pentingnya kedudukan literasi sains sebagai output pembelajaran sains, serta keterkaitannya dengan kontekstualitas kajian sains (kelautan untuk wilayah kepri)

b. Pelatihan bagi guru-guru biologi dan kimia untuk menentukan konten-konten dalam pelajaran biologi dan kimia yang dekat kaitannya dengan wawasan kemaritiman.

c. Pelatihan bagi guru-guru biologi dan kimia untuk mendesain pembelajaran bermuatan wawasan kemaritiman dengan tujuan membangun literasi sains peserta didik 
JURNAL ANUGERAH. November 2019; I(1): 25 - 31

2. Do

Pelatihan pelaksanaan proses pembelajaran menerapkan desain pembelajaran yang sudah dibuat

3. Check dan Act

Pembahasan dan tindak lanjut terhadap desain untuk menyempurnakan desain pembelajaran

\section{Hasil dan Pembahasan}

Kegiatan pengenalan dan pelatihan mendesain pembelajaran berbasis literasi sains dan bermuatan wawasan kemaritiman menghasilkan output berupa rancangan desain dan integrasinya di dalam RPP dan LKS pembelajaran pada materi terkait. Berdasakan hasil diskusi guru dan pendampingan oleh fasilitator pelatihan, maka dihasilkan kesimpulan bahwa konteks kemaritiman dapat diintegrasikan dalam materi Keanekaragaman Hayati (untuk mata pelajaran Biologi) dan materi Minyak Bumi (untuk mata pelajaran Kimia).

Kegiatan dilanjutkan dengan membuat desain pembelajaran mengikuti pola pendekatan Science and Technology Literacy (STL) yang memiliki 5 unsur kegiatan pembelajaran yaitu kontak, konteks, kuriositi, pengambilan keputusan dan nexus (Yulita, 2017).

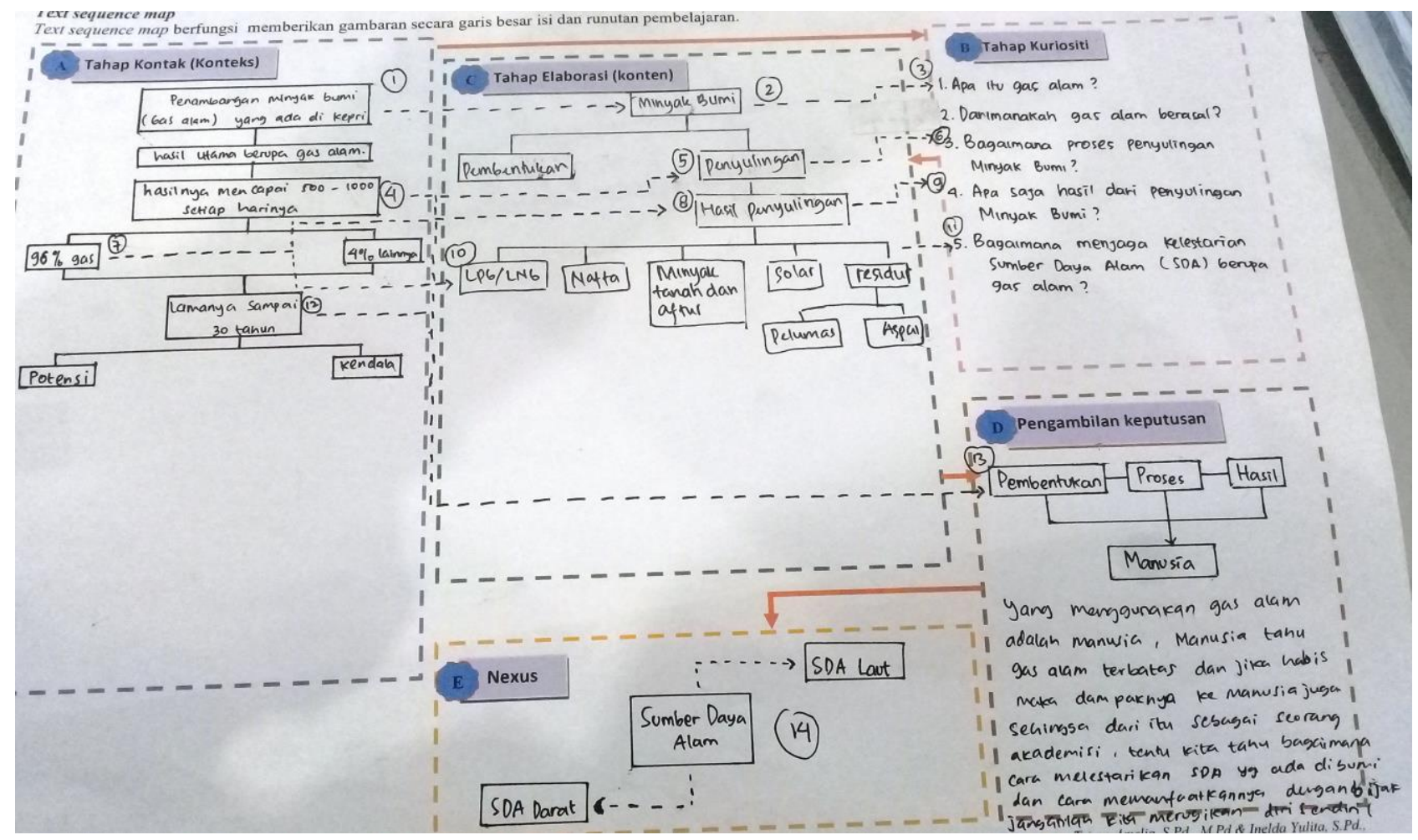

Gambar 1. Desain pembelajaran kimia

Dalam desain pembelajaran pada mata pelajaran Kimia, kelompok guru memutuskan untuk mengangkat wacana pengeboran minyak dan gas lepas pantai yang ada di provinsi Kepri sebagai konteks dalam pembelajaran. Secara hirarkis, guru menggiring wacana-wacana kontekstual kepri untuk mengarahkan daya pikir siswa sehingga relevan dengan konsep mengenai minyak bumi secara umum. Pada tahapan kuriositi, guru membuat perkiraan perntanyaan apa yang mungkin muncul dan dapat digiring siswa untuk menanyakannya. Terdapat 5 item pertanyaan yang dibuat oleh guru pada tahap kuriositi. Pada tahapan pengambilan keputusan, guru mengarahkan siswa memiliki pemahaman bahwa manusia merupakan faktor kunci dalam memproses dan mengeksplorasi kekayaan laut kepri dalam hal pertambangan minyak, sehingga 
muncul kesadaran bahwa pemanfaatan kekayaan alam harus berbasis kepada sustainability (keberlajutan). Pada tahapan nexus guru memetakan bahwa minyak bumi dapat menjadi sumber daya alam darat dan laut yang pada prinsipnya sama-sama harus dimanfaatkan dengan baik.

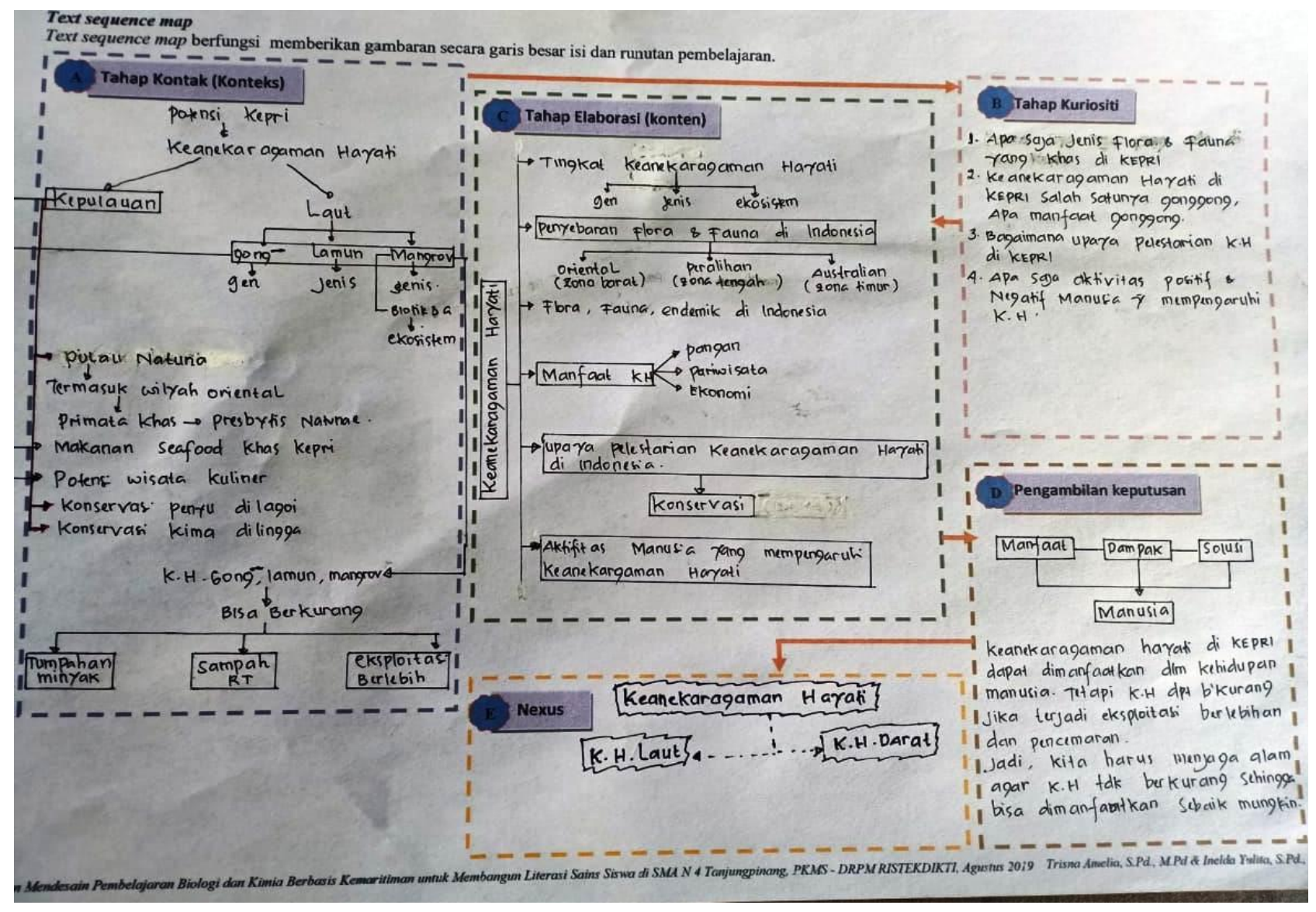

Gambar 2. Desain pembelajaran biologi

Dalam menerapkan prinsil-prinsip pembelajaran literasi sains (STL), kelompok guru biologi mengangkat wacana keunikan flora dan fauna Kepri sebagai aspek kontak pada materi keanekaragaman hayati. Keanekaragaman hayati yang ada di wilayah pesisir dan laut provinsi Kepri menjadi konteks yang akan membawa pemahaman siswa kepada konsep keanekaragaman hayati yang lebih luas. Contoh-contoh keanekaragaman hayati di laut Kepri, misalnya moluska gonggong yang lazim dikenal sebagai kuliner seafood khas Kepri menjadi topik pertama yang dipaparkan oleh guru dalam tahapan konteks. Kemudian secara lebih general, pembahasan akan mengarah kepada konsep-konsep klasifikasi keanekaragaman hayati, upaya pelestarian dan ancaman terhadap keanekaragaman hayati. Tahap kuriositi yang bertujuan untuk menstimulus critical thinking peserta didik diarahkan oleh guru kepada pertanyaan-pertanyaan yang mengaitkan antara konteks dan konten, yaitu: apa saja jenis flora dan fauna khas di Kepri?, apakah manfaat dari gonggong yang merupakan fauna khas Kepri. Pada tahap pengambilan kesimpulan dalam STL, guru menrancang bahwa kesimpulan yang akan ditarik siswa diarahkan kepada bahwa manusia memiliki peran penting untuk menjaga kelestarian keanekaragaman hayati, terutama di daerah tempat tinggal sendiri. Pada tahapan nexussiswa diarahkan untuk dapat mengasosiasikan pemahaman tentang keaneragaman hayati dari mengkaji contoh-contoh yang ada dilingkungan sekitarnya yaitu pesisir dan laut ke konteks yang lebih luas (darat). 
Desain yang sudah dibuat oleh kelompok guru, kemudian dibahas bersama, kemudian diintegrasikan ke dalam perangkat pembelajaran (RPP, dan LKPD). Perangkat pembelajaran yang dibuat kemudian diterapkan dalam pembelajaran di kelas (real teaching). Proses real teaching dilakukan secara bergantian pada jam pelajaran biologi dan kimia dengan pada tanggal 9 dan 10 September 2019. Tahapan ini diobservasi oleh guru-guru biologi dan kimia lain yang terlibat di dalam kegiatan. Setelah mengaplikasikan desain pembelajaran, pelaksana program bersama kelompok guru melakukan diskusi untuk merefleksi keterlaksanaan desain pembelajaran yang sudah dibuat sebelumnya.

Secara umum, desain yang dibuat guru sudah sesuai dengan prinsip-prinsip pembelajaran berbasis literasi sains dan sudah memiliki muatan kemaritiman. Desain yang telah dibuat kemudian diaplikasikan guru dikelas dalam proses real teaching. Berikut beberapa dokumentasi proses real teaching.

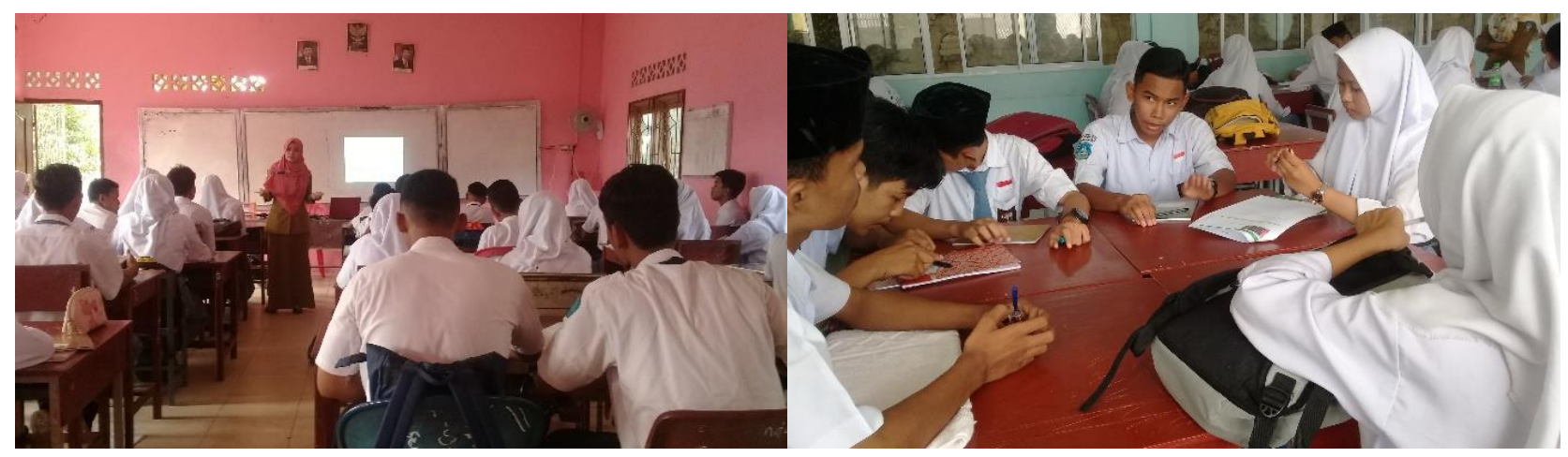

Gambar 3. Proses penerapan desain pembelajaran di kelas (realteaching)

Dari proses real teaching yang dilaksanakan dapat dilihat bahwa desain pembelajaran yang guru buat terintegrasi dengan baik di dalam RPP guru. Dalam penerapannya guru sudah mampu mengaplikasikan sebagian besar tahapan pembelajaran dengan pendekatan pengembangan literasi sains (STL) dan mampu mengaitkan konten pembelajaran dengan konteks kemaritiman.

\section{Kesimpulan}

Kegiatan pelatihan yang dilaksanakan di SMA N 4 Tanjungpinang memberikan informasi dan pengalaman baru bagi guru-guru biologi dan kimia. Kemampuan guru dalam mendesain dan mengimplementasikan desain pembelajaran bermuatan wawasan kemaritiman dan berorientasi literasi sains meningkat namun perlu terus dilatih sehingga menjadi konsisten. Dukungan dan respon dari pihak sekolah menjadi faktor pendukung keberhasilan kegiatan pelatihan yang dilaksanakan. Kegiatan lanjutan dengan tema serupa sangat direkomendasikan kedepannya. Desain pembelajaran berbasis literasi sains dan bermuatan konteks kemaritiman dapat diaplikasikan oleh guru dalam pembelajaran dengan terlebih dulu mengintegrasikannya di dalam RPP, LKS, dan perangkat mengajar lainnya.

\section{Saran}

Dari refleksi terhadap pelaksanaan progam yang sudah dilakukan, dapat disarankan kepada pihak sekolah untuk dapat memfasilitasi dan memberikan dukungan lebih besar terhadap kegiatan-kegiatan serupa. Kepada guru disarankan untuk dapat meningkatkan wawasan tentang literasi sains dan kematiriman dengan memperluas bahan bacaan dan menggali potensi lokal untuk diterapkan dalam pembelajaran. 


\section{Ucapan Terimakasih}

Ucapan terima kasih disampaikan kepada DRPM DIKTI yang telah mendanai Program Kemitraan Masyarakat Stimulus (PKMS) ini. Terima kasih juga disampaikan kepada Dr. Darson, M.Pd., yang telah memberikan kesediaan untuk menjalin kemitraan dengan penyelenggaran kegiatan ini.

\section{Referensi}

Diana, S., Rachmatullah, A., \& Rahmawati, A.S. (2015). Profil kemampuan literasi sains siswa SMA berdasarkan instrumen Scientific Literacy Assesments (SLA). Prosiding seminar nasional XII $\begin{array}{llllll}\text { Pendidikan Biologi } & \text { FKIP } & \text { UNS } & \text { Retrieved } & \text { from }\end{array}$ https://media.neliti.com/media/publications/171085-ID-none.pdf

Lestari, I.D. (2017). Pengaruh literasi sains terhadap kemampuan kognitif siswa pada konsep ekosistem. Prosiding Seminar Nasional Pendidikan FKIP UNTIRTA. Retrieved from .https://jurnal.untirta.ac.id/index.php/psnp/article/download/103-106/1715

OECD. (2013). PISA 2012 Assessment and analytical framework : Mathematic, reading, science, problem solving and financial literacy. OECD Publishing.

Snow, C. E., \& Dibner, K.A. (2016). Science literacy concepts, contexts, and consequences. Washington (DC): National Academies Press (US).https://www.ncbi.nlm.nih.gov/books/NBK396090/pdf/Bookshelf_NBK396090.pdf

Wenning, C. J. (2011). The levels of inquiry model of science teaching. Journal Physics Teacher Education Online. 6(2):9-16.

Yulita, I. (2017). Analisis prekonsepsi siswa terhadap kemampuan menghubungkan konteks air laut dengan konten hakikat ilmu kimia kelas X SMA. Jurnal Pendidikan Sains, 6(1), 64-72. https://jurnal.unimus.ac.id/index.php/JPKIMIA/article/view/3130

Yulita, I. (2017). Desain bahan ajar berbasis literasi sains: hakekat ilmu kimia pada konteks air laut. $\begin{array}{llll}\text { Prosiding } & \text { Seminar } & \text { Nasional } & \text { Kimia. }\end{array}$ seminar.uny.ac.id/semnaskimia/content/semnas2017 